\title{
Diagnosis and Management of Leprosy
}

\author{
Medhi Denisa Alinda ${ }^{1}$, Silvani Geani ${ }^{1}$, Regitta Indira Agusni ${ }^{1}$, Bagus Haryo \\ Kusumaputra $^{1}$, Novianti Rizky Reza ${ }^{2}$, Cita Rosita Sigit Prakoeswa ${ }^{1}$, Muhammad \\ Yulianto Listiawan ${ }^{1}$ \\ ${ }^{I}$ Department of Dermatology and Venereology, Faculty of Medicine, Universitas Airlangga/Dr. \\ Soetomo General Academic Teaching Hospital, Surabaya, Indonesia \\ ${ }^{2}$ Department of Dermatology, Erasmus University Medical Center, Rotterdam, The Netherlands
}

\begin{abstract}
Background: Leprosy is a chronic infectious disease caused by Mycobacterium leprae, which tends to attack peripheral nerves and skin. The diagnosis of leprosy is based on the presence of one of three cardinal signs. Early diagnosis of leprosy is critical and is made through clinical examination and investigation. Purpose: To discuss the diagnosis, laboratory examination, and treatment of leprosy, considering that early diagnosis and appropriate treatment are the key elements in breaking the chain of transmission and preventing leprosy patients' disabilities. Review: Leprosy is a chronic granulomatous infectious disease caused by the Mycobacterium leprae. Based on clinical appearance, histopathology findings, and immunological, leprosy is grouped into six forms using the Ridley-Jopling classification, namely Tuberculoid (TT), Borderline Tuberculoid (BT), Borderline-borderline Mid-borderline (BB), Borderline-lepromatous (BL), Subpolar Lepromatous (LLs), and Polar Lepromatous (LLp). Based on the treatment category, leprosy is grouped into paucibacillary (PB) and multibacillary (MB). Leprosy is often diagnosed clinically, and skin scraping smear remains the preferred laboratory method. The negative results of smear skin scraping may not necessarily exclude leprosy. Therefore, a higher sensitivity test might be needed to detect $M$. leprae. Treatment with Multi-Drug Therapy (MDT) is adjusted based on the type of leprosy, whether it belongs to the PB or MB group. Treatment of PB type, regimens are rifampicin and dapsone, while in MB type, the patients received rifampicin, dapsone, and clofazimine regimens. Conclusion: A proper diagnosis for leprosy, both through physical examination and laboratory examination, is required to determine an effective MDT treatment and break the chain of disease transmission.
\end{abstract}

Keywords: leprosy, diagnosis, management.

Correspondence: Medhi Denisa Alinda, Department of Dermatology and Venereology, Faculty of Medicine Universitas Airlangga/ Dr. Soetomo General Academic Teaching Hospital, Jl. Mayjen Prof. Dr. Moestopo No 6-8 Surabaya 60131, Indonesia, Phone+6285645040746, email: queen_merci@yahoo.com

\section{BACKGROUND}

Morbus Hansen, better known as leprosy, is a chronic infectious disease caused by Mycobacterium leprae, which tends to attack peripheral nerves and skin. This disease has been known as far back as 3000 years ago, and its estimated origin was Asia or Africa. The term leprosy was coined in an appreciation to a Norwegian doctor, Gerhard Armauer Hansen, who was the first to discover that Mycobacterium leprae is the causative bacterium of leprosy. ${ }^{1,2}$

The World Health Organization (WHO) data of 2017 suggests that Indonesia is one of the top 3 countries with the highest new leprosy cases. India, Brazil, and Indonesia contribute as much as $80.2 \%$ of new leprosy cases worldwide. There were 15,910 new cases in Indonesia. During 2015-2017, the were 3,373 new leprosy cases East Java, 1,813 new cases in West
Java, 1,644 in Central Java, and 1,091 in South Sulawesi. ${ }^{3-5}$

Leprosy diagnosis is determined as one out of three cardinal signs is present: (i) loss of sure sensation in pale (hypopigmented) or reddish skin; (ii) thickening of peripheral nerve or (iii) the presence of acid-fast bacilli/AFB in the skin scraping. The Multibacillary (MB) leprosy type has a positive AFB test result. Several other tests, including histopathology examination, serology, include PGL-1 antibody titer, and Polymerase Chain Reaction (PCR) examination. A diagnostic examination in the milder form of leprosy (Paucibacillary/PB leprosy) still poses as quite a challenge. Although PCR-based tests provide higher sensitivity and specificity than enzyme-linked immunosorbent assay (ELISA), it would be quite impractical for daily practice. Current research 
prioritizes on specific molecular identification for $M$. leprae and development of sensitive laboratory tests to diagnose asymptomatic cases or the ones with fewer symptoms, as well as predicting the development of disease among exposed individuals. ${ }^{6-8}$

A problem that interferes with the attempt to tackle leprosy is the stigma or negative outlook on the patients and their families. This stigma also causes the sufferer to refrain from seeking treatment out of fear for their condition being known by their peers. Indeed, it's necessary promoting strategies to cut off the chain of transmission that can spreading this infection and aggravating the occurrence of disability in leprosy patients. $^{5}$

Early diagnosis of leprosy is critical to make sure the sufferers receive adequate Multi-Drug Therapy (MDT) treatment appropriate to the type of leprosy as government regulations. A precise early diagnosis and treatment are key elements in breaking the chain of transmission and preventing disability on the patients. ${ }^{7}$ Thus, this review will further discuss the diagnoses, additional examinations, and therapies for leprosy.

\section{REVIEW}

Leprosy is a chronic granulomatous infection caused by intracellular obligate Mycobacterium leprae bacilli, which tends to attack the skin and peripheral nerves, causing neuropathy, chronic abnormalities, and disability. Depending on the type of leprosy, the involvement of the reticuloendothelial system, bone and joint, eyes, testicles, muscles, adrenals, and other areas may occur. The transmission of leprosy takes place between humans through long-term and close contact with untreated MB-typed patients. ${ }^{6,9,10}$

WHO has been collecting data on the prevalence of leprosy each year, covering new and treated cases. According to WHO, in 2017, India, Brazil, and Indonesia cumulatively recorded $80.2 \%$ new leprosy cases. In Indonesia, the number of new cases decreased from 17,202 in 2015 to 16,826 in 2016 and further decreased to 15,910 in 2017 . The highest number of new cases was in 2011 with 20,023 cases. $^{3,4}$

According to its clinical, histopathological, and immunological criteria, leprosy is grouped into 6 forms using the Ridley-Jopling classification (1962), which are Tuberculoid (TT), Borderline Tuberculoid (BT), Borderline-borderline Mid-borderline (BB), Borderline-Lepromatous (BL), Subpolar Lepromatous (LLs), and Polar Lepromatous (LLp). To facilitate its treatment, leprosy is divided into 2 groups according to WHO, the paucibacillary (PB) and multibacillary (MB) type. ${ }^{1,9,11}$

Table 1. The clinical appearance of leprosy ${ }^{1,9}$

\begin{tabular}{|c|c|c|c|c|c|}
\hline Feature & Tuberculoid & $\begin{array}{l}\text { Borderline } \\
\text { tuberculoid }\end{array}$ & Midborderline & $\begin{array}{l}\text { Borderline } \\
\text { lepromatous }\end{array}$ & Lepromatous \\
\hline $\begin{array}{l}\text { Number of } \\
\text { lesions }\end{array}$ & $\begin{array}{l}1 \text { or more than } \\
3\end{array}$ & More than 10 & $10-30$ & $\begin{array}{l}\text { Lots, } \\
\text { asymmetrical } \\
(>30)\end{array}$ & $\begin{array}{l}\text { Copious, } \\
\text { symmetrical }\end{array}$ \\
\hline Size & $\begin{array}{l}\text { Varies, usually } \\
\text { large }\end{array}$ & $\begin{array}{l}\text { Varies, several } \\
\text { lesions are } \\
\text { larger }\end{array}$ & Varies & $\begin{array}{l}\text { Small, some are } \\
\text { larger }\end{array}$ & Small \\
\hline Surface & Dry, scaly & Dry, scaly & $\begin{array}{l}\text { Rather rough, } \\
\text { rather shiny }\end{array}$ & Smooth, shiny & Smooth, shiny \\
\hline Anesthesia & Obvious & Obvious & More obvious & Unclear & Usually unclear \\
\hline AFB & Negative & Negative or $1+$ & $1-3+$ & $3-5+$ & $\begin{array}{l}\text { Lots, globus are } \\
\text { present }(6+)\end{array}$ \\
\hline $\begin{array}{l}\text { Lepromin } \\
\text { test }\end{array}$ & $\begin{array}{l}\text { Strongly } \\
\text { positive }\end{array}$ & $\begin{array}{l}\text { Weakly } \\
\text { positive }\end{array}$ & Negative & Negative & Negative \\
\hline
\end{tabular}

The clinical diagnosis is confirmed if two out of three criteria are present, or there are AFB bacteria in the skin scraping, or a typical histological characteristic for leprosy is found. The cardinal signs for leprosy include (1) Hypopigmentation or erythematous skin lesions, such as macule or plaque, accompanied by the loss of sensation on the skin; (2) Thickening or enlargement of peripheral nerves and signs of its damage, such as loss of sensory, paralysis, or motoric dysfunction with or without nerve enlargement; (3) The presence of acid-fast bacilli (AFB) on skin lesion scraping and/or biopsy. Early and precise diagnosis of leprosy is critical in preventing irreversible damage to the nerves. ${ }^{8,12-14}$

Two predominating characteristics of suspected leprosy patients are the type of lesion and its 
distribution on the body. Under the context of diagnosis purposes, the variable nature of leprosy will greatly aid in pin-pointing the symptoms on the skin. ${ }^{15} \mathrm{~A}$ single or several grouped macules represents an unclear or intermediate leprosy diagnosis. In addition to the intermediate leprosy clinical manifestation, the occurrence of several macules might be an early stage of lepromatous leprosy. Therefore, it is strongly advised to do a bacteriological examination of specimens from these kinds of lesion. ${ }^{15}$

A tuberculoid lesion is solitary and few (less than 5) with either unilateral to bilateral distribution or asymmetrical. The lesion might appear hypopigmented or erythematous. A tuberculoid lesion typically occurs as a wide erythematous plaque with well-demarcated edges, elevated border, and a flat center. The most commonly affected areas are the face, extremities, trunk, axilla, groin, and perineum. A tuberculoid lesion is anesthetic or hypoesthetic and anhidrotic, accompanied by an enlargement of the proximal superficial peripheral nerve of the lesion. ${ }^{15,16}$

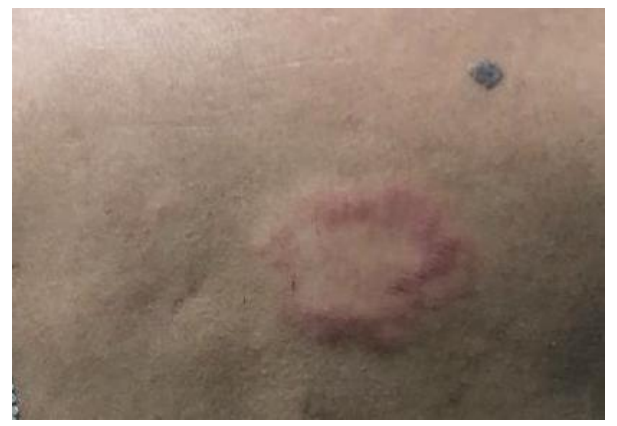

Figure 1. Tuberculoid Leprosy: single lesion, anesthetic and annular. ${ }^{2,11}$

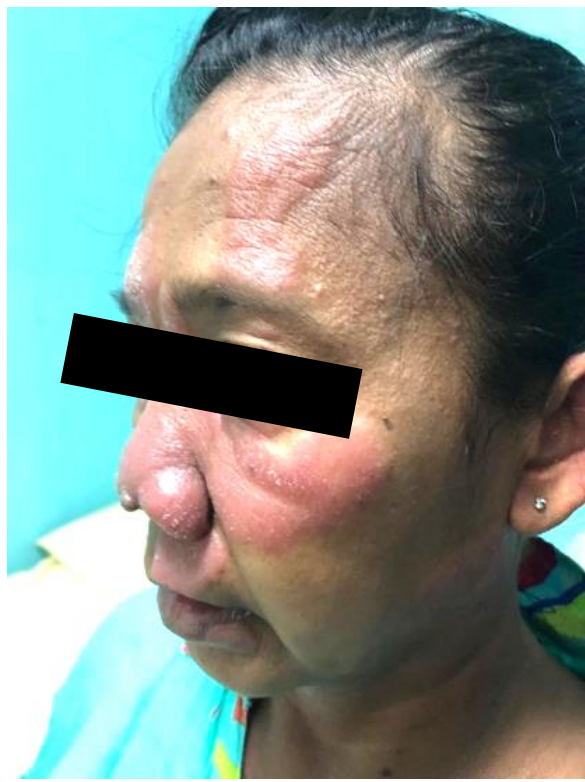

Figure 2. Borderline leprosy: Elevated facial lesion. ${ }^{13}$
The tuberculoid borderline lesion is similar to that of tuberculoid lesion, only with smaller size and larger quantity. Paucibacillary lesion tends to scatter and might be grouped. The skin tends not to produce sweat, causing the affected surface to appear dry and coarse. Macules and plaques might appear ring-like, indicating the occurrence of central healing. Papules might appear grouped, forming a plaque or a border of macule or annular lesions. Around the larger lesions (BT), where the edges are less demarcated, smaller satellite lesions might appear. Enlarged or protruding nerves might be palpated near larger infiltrated lesion. ${ }^{15}$

There are more lesions in borderline leprosy (still countable), which consist of irregular red plaques. A smaller satellite lesion surrounds the larger plaque asymmetrically. The lesion's borders are less demarcated than the tuberculoid type, and there might be nerve enlargement. ${ }^{15,16}$ Borderline lepromatous (BL) type has a symmetrical, copious lesion, and might consist of macules, papules, plaques, and nodules. The number of small lesions on the lepromatous type exceeds that in any other borderline type. Nerve involvement appears afterward. The nerve will enlarge, become painful, or both. The patients usually do not exhibit typical characteristics as seen in lepromatous leprosy such as madarosis, keratitis, nasal ulceration, and leonine facies. ${ }^{16}$

The lepromatous leprosy cutaneous lesion consists of pale macules or diffuse infiltration on the skin. The macule lesions are symmetrically scattered, small-sized, and copious, in contrast to a tuberculoid lesion, which is larger and fewer. In macules, there is no alteration in skin texture, and it blends with the surrounding skin. The sensation is not diminished or might be lessened slightly on the lesion, no nerve enlargement, and no sweat alteration. There is a loss of the outer third of the eyebrows, followed by eyelashes and trunk hair. However, there is no alteration on the scalp hair. ${ }^{15,16}$

Sensory loss on the lesion area and the distal extremities needs to be checked using cotton, nylon thread, or pen tip examination. The three modalities, touch, pain, and temperature function have to be evaluated as well. Due to the rich nerve supply on the face, sensory alteration tends to be unclear in this area compared to other body parts. The diagnosis of PB, particularly tuberculoid leprosy, depends on those simple procedures. The presence of one or more chronic skin lesion accompanied by anesthesia or hypoesthesia directs the diagnosis to leprosy. ${ }^{13}$

There are currently no laboratory tests considered adequate for the diagnosis of leprosy. The additional examination consists of slit-skin smear, serological, histopathological, molecular examination and also 
other tests such as the Mitsuda intradermal reaction can help establish the diagnosis in doubtful cases. Slit skin smear examination is a simple microscopic examination to see the presence of acid-resistant bacteria. This test is easy to do and gives good results if done by experienced staff. Slit-skin smear examination is useful in the stages of diagnosis, classification, monitoring of treatment and observation the disease severity. ${ }^{18}$ However, this examination cannot detect leprosy before the number of bacilli reaches a certain amount. So a negative slit-skin smear may not necessarily exclude leprosy. Therefore, a test with better sensitivity might be needed to detect $M$. leprae. ${ }^{7,19,20}$ Skin biopsy is a histopathological examination with adequate accuracy in lesion classification. A biopsy is useful to confirm diagnosis, prognosis, and evaluate the therapy. A peripheral nerve biopsy is a useful tool in diagnosing leprosy whenever physical examination and a skin biopsy is inconclusive. The histopathological characteristic of tuberculoid leprosy is the presence of epithelial cell granulomas. This is under the presumption that the M. leprae lies on the Schwann cells of the nerve, particularly on colder areas, places of trauma, or superficial parts of trapped nerves. Nerve lesion on lepromatous leprosy (LL) is characterized by bacterial multiplication without inhibition, mainly on Schwann cells, due to the lack of efficient cellular immunity against $M$. leprae. In BBLL leprosy, there is focal and diffuse nerve involvement. ${ }^{13,21,22}$

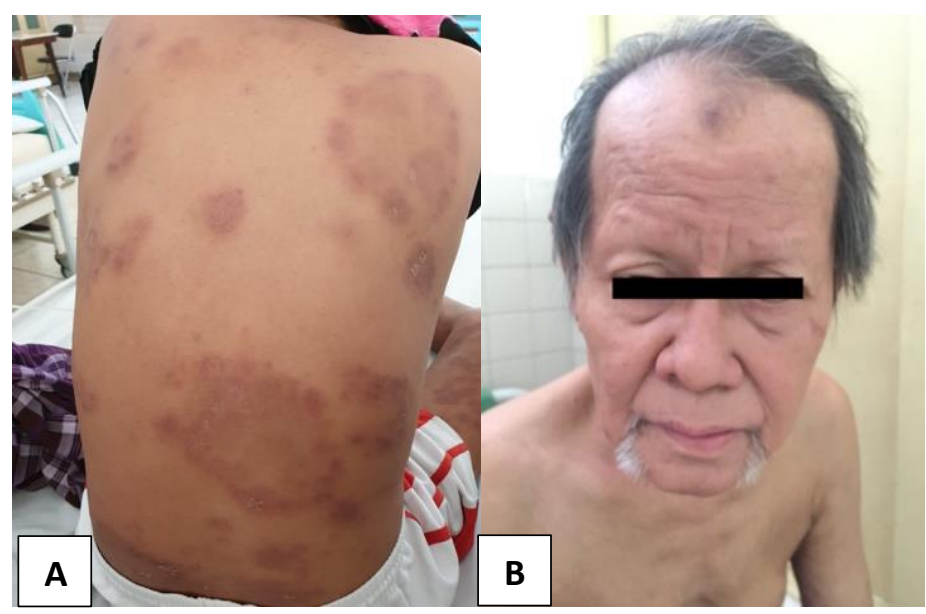

Figure 3. Borderline lepromatous leprosy: Multiple scattered plaques (A). Lepromatous leprosy: madarosis (B). ${ }^{2,13}$

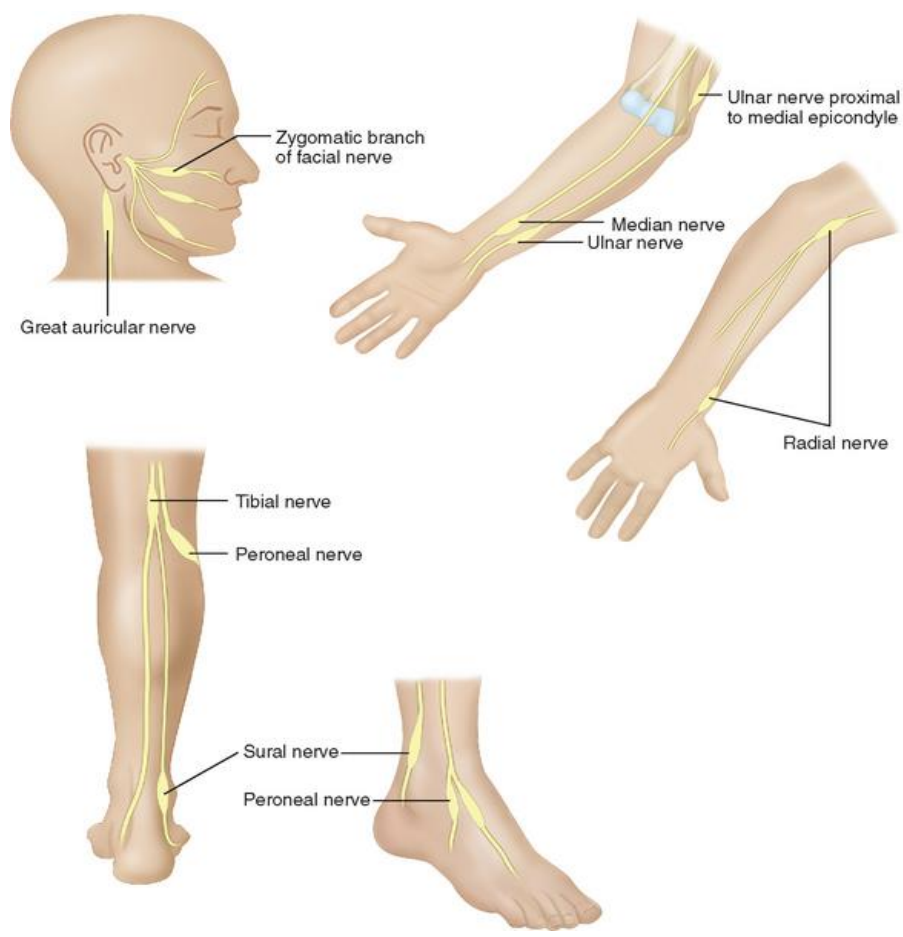

Figure 4. The most commonly affected nerves in leprosy. ${ }^{17}$ 
Immunohistochemistry reaction using a monoclonal or polyclonal antibody to detect $M$. leprae antigen promises better sensitivity and specificity compared to conventional methods, an important tool in diagnosing leprosy, particularly on early phase or in PB leprosy. Some antibodies are used in the diagnosis, for example, the ones directed to protein (e.g., S-100 and heat shock protein such as $35 \mathrm{kDa}$ and $65 \mathrm{kDa}$ ), and against lipoarabinomannan and phenolic glicolipid-1 (PGL-1). Except for anti-PGL-1 antibody, which is directed to the specific antigen for M. leprae, and the remaining antibodies can trigger a positive result in normal skin or several chronic communicable or autoimmune disease. ${ }^{7}$

In some patients, these nerves are damaged beyond recognition under routine histopathological examination. A coil of spindle-shaped Schwann cells might be difficult to distinguish from a group of epitheloid. S-100 dye that selectively colors Schwann cells might be used to release remaining damaged nerves in the tuberculoid granuloma. Some publications highlight the dye's benefits in diagnosing tuberculoid leprosy and distinguishing them from other tuberculoid granulomas on the skin such as tuberculosis, deep fungal infection, and sarcoidosis. Positive staining might eliminate leprosy if it shows intact nerve end due to other granulomatous diseases. Monoclonal antibody (Mab), MLO4, which reacts explicitly with $35 \mathrm{kDa}$ epitope of $M$. leprae, is used to detect antibodies in leprosy patients. With this test, nearly $100 \%$ of active BL/LL and more than $40 \%$ TT/BT patients bear positive result. ${ }^{23,24,25,26,27}$

Pemeriksaan serologis kusta adalah pilihan yang murah, mudah, dan bisa dilakukan di lapangan Pada saat ini pemeriksaan serologis terhadap antibody PGL1. The chemical structure of an antigen has been discovered, particularly PGL, aiding in the revolution in leprosy serodiagnostic, which turns out, can be found in $M$. leprae-infected armadillo tissues. Some studies have evaluated the benefit of PGL-1 in estimating the probability of a contact that becomes leprosy patient. A positive PGL-1 in contact carries three times the risk of developing leprosy. The presence of anti-PGL-1 antibody aids in classifying the clinical feature, in which $\mathrm{MB}$ patients exhibit higher antibody titer while PB shows little to none, with the PGL-1 seropositive patient percentage ranges from 80 $100 \%$ in lepromatous leprosy and $30-60 \%$ in tuberculoid leprosy. Increased PGL-1 antibody in treated patients indicates the recurrence of the disease. The PGL-1 antigen is water-insoluble; therefore, it stays in tissues for quite a long time, which in turn triggers IgM antibody production in the absence of living bacilli. Thus, the presence of anti-PGL-1 antibody does not necessarily mean an active disease. ${ }^{7,28,29,30,31}$

Serological tests using antigens other than phenolic glycolipids-I (PGL-I) which are also widely studied include analogs in trisaccharide, NDO and NTP. In addition, diagnostic markers include antibodies to Leprosy IDRI Diagnostic-1 (LID-1), which is a blend of ml0405 and ml2331 gene products, as well as antibodies against NDO-LID, the conjugate of natural octac disaccharide (NDO) and LID. Recently, the conjugation between natural octac disaccharide (NDO) and IDRI leprosy diagnostic (LID) -1, known as NDO-LID, shows great possibility because of its high specificity and sensitivity and ability to detect leprosy before any clinical signs. ${ }^{32,33}$

Another examination includes polymerase chain reaction (PCR), a simple and sensitive diagnostic tool used to detect, measure, and determine the viability of M. leprae, which significantly shows better results than other general microscopic examinations. This is based on specific sequence amplification of the M. leprae genome and deoxyribonucleic acid (DNA) or ribonucleic acid (RNA) fragments identification. PCR allows early confirmation, PB and pure nerve leprosy, subclinical contact infection, therapy evaluation, recovery decision, or identification of resistant individual against MDT, and aids in understanding the mechanism of $M$. leprae transmission. PCR can detect $M$. leprae even before symptoms occur in the high-risk group (contact within the household). M. leprae investigation by PCR has been done with various samples, such as swabs, fragment biopsy, or skin biopsy, nasal swab, urine, nerve, lymph nodes, and hair. $7,20,34,35,36,37$

Table 2. Multi-Drug Therapy for Paucibacillary type

\begin{tabular}{lllll}
\hline Drugs & $<10$ years & $10-15$ years & $>15$ years & Note \\
\hline Rifampicin & $300 \mathrm{mg} / \mathrm{month}$ & $450 \mathrm{mg} / \mathrm{month}$ & $600 \mathrm{mg} / \mathrm{month}$ & $\begin{array}{l}\text { Taken in front of } \\
\text { an officer } \\
\text { Dapsone }\end{array}$ \\
& $25 \mathrm{mg} / \mathrm{month}$ & $50 \mathrm{mg} / \mathrm{month}$ & $100 \mathrm{mg} / \mathrm{month}$ & $\begin{array}{l}\text { Taken in front of } \\
\text { an officer } \\
\text { Taken at home }\end{array}$ \\
\hline
\end{tabular}

Duration of therapy: treatment is given in 6 doses during $6-9$ months ${ }^{9,16,38,39}$ 
Table 3. Multi-Drug Therapy for Multibacillary type

\begin{tabular}{lllll}
\hline \multicolumn{1}{c}{ Drugs } & \multicolumn{1}{c}{$<10$ years } & \multicolumn{1}{c}{$10-15$ years } & \multicolumn{1}{c}{$>$ Note } \\
\hline Rifampicin & $300 \mathrm{mg} / \mathrm{month}$ & $450 \mathrm{mg} / \mathrm{month}$ & $600 \mathrm{mg} / \mathrm{month}$ & $\begin{array}{l}\text { Taken in front of } \\
\text { an officer }\end{array}$ \\
Dapsone & $25 \mathrm{mg} / \mathrm{month}$ & $50 \mathrm{mg} / \mathrm{month}$ & $100 \mathrm{mg} / \mathrm{month}$ & $\begin{array}{l}\text { Taken in front of } \\
\text { an officer }\end{array}$ \\
& $25 \mathrm{mg} /$ day & $50 \mathrm{mg} /$ day & $100 \mathrm{mg} /$ day & $\begin{array}{l}\text { Taken at home } \\
\text { Taken in front of } \\
\text { an officer } \\
\text { Clofazimine }\end{array}$ \\
$\begin{array}{llll}\text { (Lamprene) } \\
100 \mathrm{mg} / \mathrm{month}\end{array}$ & $150 \mathrm{mg} / \mathrm{month}$ & $300 \mathrm{mg} / \mathrm{month}$ & Taken at home \\
& $50 \mathrm{mg}$ twice a week & $50 \mathrm{mg}$ once every & $50 \mathrm{mg} /$ day & \\
\hline
\end{tabular}

Duration of therapy: treatment is given in 12 doses in 12-18 months s,16, 38,39 $^{9}$

Leprosy is treated with MDT WHO $(1998,2012)$. The MDT regimen is adjusted according to the type of disease, $\mathrm{PB}$, and MB.

Rifampicin is a semisynthetic derivate of Rifamycin, an antibiotic acquired from Streptomyces mediterranei bacterial fluid suspension. Rifampicin should not be given as monotherapy due to its resistance-triggering effect. This medication possesses potent antibacterial property, eradicating more than $99.99 \%$ M. leprae bacteria with its single dose of 1500 $\mathrm{mg}$ or as 3 to 4 daily doses of $600 \mathrm{mg}$. Rifampicin causes an alteration in urine, ear, and sweat color into red-orange without any further consequence; however, patients have to be informed prior to taking the first dose. Rifampicin is able to penetrate through the bloodbrain barrier and placenta. Due to its solubility in fat, rifampicin permeates through cell membranes, supporting its effectiveness in eradicating intracellular bacteria. ${ }^{19,40,41,42,43}$

The clinical effect of rifampicin can be seen quickly. In lepromatous leprosy, defects on the nose will lessen in 2 to 3 weeks, while skin lesion subsides within 2 to 3 months. Skin preparation coloring will show a rapid decline in its morphological index. In bacil coloring, there will be no bacteria seen within 4 to 6 weeks of Rifampicin treatment. M. leprae acquired from biopsy samples will show no surviving bacteria after 4 to 7 days of treatment. ${ }^{40,44}$

Intolerance to Rifampicin might be due to allergy, comorbidities such as chronic hepatitis, or Rifampicinresistant bacterial infection. Patients who are infected with Rifampicin-resistant bacteria are usually also resistant to Dapsone. Therefore, there is an alternative regimen as follows. ${ }^{9,16,45}$

Table 4. Regimen for patients who cannot take Rifampicin ${ }^{9,16,43}$

\begin{tabular}{lll}
\hline Duration & Drug Type & Dose \\
\hline First 6 months & Clofazimine & $50 \mathrm{mg} / \mathrm{day}$ \\
& added with 2 out of the following 3 & \\
& drugs: & \\
& Ofloxacin & $400 \mathrm{mg} / \mathrm{day}$ \\
& Minocycline & $100 \mathrm{mg} / \mathrm{day}$ \\
& Clarithromycin & $500 \mathrm{mg} / \mathrm{day}$ \\
Continued for 18 months & Clofazimine & $50 \mathrm{mg} / \mathrm{day}$ \\
& with ofloxacin & $400 \mathrm{mg} / \mathrm{day}$ \\
& OR & \\
& Minocycline & $100 \mathrm{mg} / \mathrm{day}$ \\
\hline
\end{tabular}

Dapsone (4.4 diaminodiphenyl sulfone) is a sulfa group drug first synthesized in 1908. Dapsone-the main ingredient of derivates-diaminodiphenyl sulfone (DDS/dapsone) is currently accepted as an active molecule. Since the early 60s, Dapsone has been continuously utilized as the main drug against leprosy. The normal dose of Dapsone for adults is $100 \mathrm{mg} / \mathrm{day}$ and $2 \mathrm{mg} / \mathrm{kg} /$ day for children. Its half time is approximately 24 hours. In multibacillary (borderline and lepromatous type) leprosy, the clinical response will be visible within 3-6 months after the initial Dapsone therapy. However, complete clinical regression will need longer time, usually up to 2 to 3 years. ${ }^{40,41}$

The clinical response of paucibacillary (TT and BT) leprosy patient quite varies; about $2 / 3$ of patients experience complete healing within 6 months, while the rest might need more than 1 year to regress. Nerve 
deficit is mostly unaffected by Dapsone. Therefore, the eyes and extremities need to be protected against trauma and burn injuries. Dapsone has a side effect, just as seen in hemolytic anemia, as well as potentially induce liver failure in some patients. The renal and liver function might be abnormal during the examination. In some cases, yellow coloration or jaundice might appear along with hepatic enlargement. It is important to mention the presence of liver damage in leprosy patients, mainly in lepromatous type, that might be caused by viral hepatitis, commonly found in leprosy endemic areas. ${ }^{40,47}$

A hypersensitivity reaction in the form of Dapsone syndrome is often seen in patients after several months of treatment. Reports have shown that the frequency increases to more than $95 \%$ of the number of cases, that is 108 cases, that occurred within the last 2 decades, mostly occurring since MDT was first introduced. Dapsone causes serious side effects such as Dapsone syndrome (drug hypersensitivity syndrome), therefore its use needs to be halted. There is no modification for MB patients; hence MDT is continued without Dapsone for 12 months. Meanwhile, in PB leprosy therapy, Dapsone is replaced with Clofazimine under the same dose as MDT for MB for 6 months. ${ }^{9,40,48}$

Clofazimine has a mild antibacterial property against $M$. leprae, its effect is a bit weaker than that of Dapsone. Studies have shown that Clofazimine accumulates in the macrophage, where $M$. leprae resides, triggering local hydroxyl and superoxide radical formation. These products inhibit $M$. leprae bacterial multiplication. The clinical response of daily 50 to $100 \mathrm{mg}$ of Clofazimine is similar to that in 100 $\mathrm{mg}$ of Dapsone, although its effect is a bit weaker. Clofazimine has a long half time; hence its supervised monthly dose of $300 \mathrm{mg}$ is also included in the regimen for multibacillary leprosy as recommended by the WHO. Almost all types of leprosy respond well to this drug, indicating its benefit. However, Clofazimine should not be used as either monotherapy or a replacement for Dapsone that is cheaper and more effective. ${ }^{40,41,49}$

Upon Clofazimine consumption, there might be an alteration of the skin color into red-brownish because its deposition on the skin increases pigmentation, which is a common finding. If the patient refuses to take Clofazimine, it can be replaced with 100 $\mathrm{mg}$ /day of Minocycline in the 12 months of MDT regimen or $400 \mathrm{mg} /$ day of Ofloxacin for 12 months or $600 \mathrm{mg} / \mathrm{month}$ of Rifampicin, $400 \mathrm{mg} / \mathrm{month}$ of Ofloxacin, and $100 \mathrm{mg} / \mathrm{month}$ of Minocycline for 24 months. ${ }^{9,16,50}$

\section{CONCLUSION}

Leprosy is a chronic infectious disease caused by Mycobacterium leprae, an intracellular obligate bacterium. It mainly attacks peripheral nerve and skin. Indonesia is in the top three countries, along with India and Brazil, with the most leprosy cases worldwide. East Java has the highest number of new leprosy cases in Indonesia. The transmission takes place between humans through long-term and close contact with the untreated patient in the multibacillary type.

To confirm the diagnosis, there are cardinal signs for leprosy. Slit-skin smear remains the main choice of additional examination for leprosy. However, this method is still not as sensitive as expected for PB type. Additional examinations to confirm diagnosis and classification are skin and nerve histopathology, serology test, histochemistry reaction, and PCR. A precise diagnosis for leprosy, either physical or additional examination, is crucial to determine the Multi-Drug Therapy (MDT) regimen and break the chain of transmission.

\section{REFERENCES}

1. Bhat RM, Prakash C. Leprosy: an overview of pathophysiology. Interdiscip Perspect Infect Dis 2012; Vol 2012(181089):1-6.

2. Lastória JC, Morgado de Abreu MAM. Leprosy: a review of the epidemiological, clinical, and etiopathogenic aspects - Part 1. An Bras Dermatol 2014;89(2):205-18.

3. World Health Organization. Weekly epidemiological record: Global leprosy update, 2015: time for action, accountability, and inclusion. WHO. Geneva; 2016, 91: 405-20.

4. World Health Organization. Weekly epidemiological record: global leprosy update, 2017: reducing the disease burden due to leprosy. WHO. Geneva; 2018, 93: 445-56.

5. Pusat Data dan Informasi Kementerian Kesehatan Republik Indonesia. 2018. Infodatin Kusta 2018. [online] Available at: <http://www.pusdatin. kemkes.go.id/download.php?file $=$ download/pus datin/infodatin/infoDatin-kusta-2018.pdf $>$

6. World Health Organization. Guidelines for the diagnosis, treatment and prevention of leprosy. New Delhi: WHO, Regional Office for South East Asia; 2018.

7. Lastória JC, Morgado de Abreu MAM. Leprosy: a review of laboratory and therapeutic aspects Parts 2. An Bras Dermatol 2014;89(3):389-403.

8. World Health Organization. WHO expert committee on leprosy eight report. Geneva: WHO; 2012.

9. PERDOSKI. Panduan praktek klinis bagi dokter 
spesialis kulit dan kelamin di Indonesia. Jakarta: PERDOSKI; 2017.

10. Cunha C. et al. A historical overview of leprosy epidemiology and control activities in Amazonas, Brazil. Rev Sociedade Bras Me Trop 2015; 48 (Suppl I):55-62.

11. Lee DJ, Rea TH, \& Modlin RL. In: Wolf K, Goldsmith LA, Katz SL, Gilchrest BA, Paller AS, Leffel DJ, editors, Fitzpatrick's dermatology in general medicine, 8 th ed. New York : McGrawHill; 2013, p.4226-43.

12. Kementrian Kesehatan RI. Pedoman nasional program pengendalian kusta. Jakarta. 2012

13. Yawalkar SJ. Leprosy for medical practicioners and paramedical workers $8^{\text {th }}$ revised ed. Basel: Novartis Foundation for Sustainable Development; 2009.

14. Lockwood DNJ. In Griffiths CEM, Barker J, Bleiker T, Chaimer R, Creeamer D, editors, Rook's Textbook of Dermatology, $9^{\text {th }}$ ed, Chichester: John Wiley \& Sons, Ltd; 2016, p 28.1-18.

15. Hastings RC. Leprosy second edition. Louisiana: Churchill Livingstone. 1994

16. James WD, Berger TG, Elston DM.Hansen's Disease. In: Andrews' diseases of the skin clinical dermatology. 11th ed. Philadelphia: Elsevier; 2011. p.336-7.

17. Sabin TD, Swift TR, Jacobson RR: Leprosy. In: Dyck PJ, Thomas PK, eds: Peripheral neuropathy. Philadelphia: Elsevier Saunders. 2005, p.2089-90, Figure 91-4.

18. Mahajan VK. Slit-skin smear in leprosy: lest we forget it! Indian J Lepr 2013; 85(4):177-83.

19. Djuanda A. Ilmu penyakit kulit dan kelamin Edisi kelima. Jakarta : Balai Penerbit FKUI; 2007.

20. Maltempe FG, Baldin VP, Lopes MA, Siqueira VLD., Scodro RBL, Cardoso RF, CaleffiFerracioli K. R. Critical analysis: use of polymerase chain reaction to diagnose leprosy. Braz J Pharm Sci 2016; 52: 163-7.

21. Manandhar U, Adhikari .C, Sayami G. Clinicohistopathological correlation of skin biopsies in leprosy. J Pathol Nepal 2013; 3:452-8.

22. Shetty VP, Rambhia KD, Khopkar US. Descriptive pathology of nerve in leprosy. Diunduh dari https://www.internationaltextbook ofleprosy.org/sites/default/files/ITL_9_1\%20FN AL.pdf. Last update 01/10/2018

23. Chatura KR, Sangeeths S. Utility of fite-faraco stain for both mast cell count and bacillary index in skin biopsies of leprosy patients. Indian J Lepr 2012; 84:209-15.
24. Tomas MM, Jacob M, Chandi SM, et al. Role of S-100 staining in differentiating leprosy from other granulomatous skin diseases. Int J Lepr 1999;67:1-5.

25. Indian Association of Leprologists. Indian Association of Leprolgists Textbook of Leprosy (Second ed.). New Delhi: Jaypee Brothers Medical Publishers (P) Ltd; 2017.

26. Rivoire BL, TerLouw S, Groathouse NA, Bennan PJ. The challenge of producing skin test antigens with minimal resources suitable for human application against a neglected tropical disease; leprosy. PLoS Negl Trop Dis 2014; 8(5): e2791 : $1-11$.

27. Kaur A, Shirazi N, Harsh M, Roy S. Role of s-100 immunostaining in differentiation of borderline leprosy from other granulomatous diseases of skin. Indian J Lepr 2018; 90: 289 -96.

28. Amirudin_MD. Penyakit kusta di Indonesia; masalah penanggulangannya, MDVI 2015; Suppl $1: 1-4$.

29. Penna MLF, Penna GO, Iglesias PC, Natal S, Rodrigues LC. Anti-PGL-1 positivity as a risk marker for the development of leprosy among contacts of leprosy cases: systematic review and metaanalysis. PLoS Negl Trop Dis 2016; 10(5): $1-11$.

30. Zenha EMR, Ferreira MAN, Foss NT. Use of anti-PGL-1 antibodies to monitor therapy regimes in leprosy patients. Braz J Med Biol Res, October 2009, Volume 42(10): 968-72.

31. Sengupta U. Recent Laboratory Advances in Diagnostics and Monitoring response to treatment in leprosy. Indian Dermatol Online $\mathrm{J}$ 2019;10(2):106-14.

32. Fabri ACOC, Carvalho APM, Vieira NF, Bueno IC, Rodrigues RN, Monteiro TBM, et al. Integrative literature review of the reported uses of serological tests in leprosy management. Rev Soc Bras Med Trop 2016;49(2):158-64.

33. Rumondor B, Prakoeswa AC, Trianita MN, Iswahyudi, Herwanto N, Listiawan MY, Agusni I, Izumi S, Duthie M, Prakoeswa CRS. Immunoglobulin AMG Anti Natural Disaccharide Octyl - Leprosy IDRI Diagnostic (NDO-LID) serologic test for leprosy diagnosis: a Pilot Study. Dermatology Reports 2019; Vol 11(s1):8025.

34. Soto A, Munoz PT. Leprosy diagnosis: an update on the use of molecular tools. Mol Biol 2015; 4 : 139-44

35. Tatipally S, Srikantam A, Kasetty S. Polymerase chain reaction (pcr) as a potential point of care laboratory test for leprosy diagnosis - a 
systematic review. Trop. Med. Infect. Dis. 2018; 3(4): 107-20.

36. Siwakoti S, Rai K, Bhattarai NR, Agarwal S, Khanal B. Evaluation of polymerase chain reaction (pcr) with slit skin smear examination (sss) to confirm clinical diagnosis of leprosy in Eastern Nepal. PLoS Negl Trop Dis 2016; 10(12): $1-11$.

37. Gurung P, Gomes CM, Vernal S, Leeflang MM. Diagnostic accuracy of tests for leprosy: a systematic review and meta-analysis. Clin Microbiol Infect 2019; 25(11):1315-27.

38. Penna GO, Bu hrer-Se' kula S, Kerr LRS, Stefani MMdA, Rodrigues LC, de Arau'jo MG, et al. Uniform multidrug therapy for leprosy patients in Brazil (U-MDT/CT-BR): results of an open label, randomized and controlled clinical trial, among multibacillary patients. PLoS Negl Trop Dis 2017; 11(7): 1-19.

39. Manickam P, Mahendale SM, Nagaraju B, Katoch K, James A, et al. International open trial of uniform multidrug therapy regimen for leprosy patients: Findings \& implications for national leprosy programmes. Indian J Med Res 2016; 144(4): 525-35.

40. Kar HK, Kumar B. IAL Textbook of leprosy. New Delhi: Jaypee Brothers Medical Publishers (P) Ltd; 2010, p.336-42.

41. Makino M, Matsuoka M, Goto M, Hatano K. Leprosy: science working towards dignity. Kanagawa: Tokai University Press; 2011, p.1467.

42. Rao PN, Jain S. Newer management options in leprosy. Indian J Dermatol 2013; 58(1):6-11.

43. Cruz RCS, Penna MLF, Talhari S, BuhrerSe' kula S, Penna GO. Leprosy: current situation, clinical and laboratory aspects, treatment history and perspective of the uniform multidrug therapy for all patients. An Bras Dermatol 2017;9 2(6): 761-73.

44. Podder I, Saha A, Bandyopadhyay D. Clinical and histopathological response to multidrug therapy in paucibacillary leprosy at the end of 6 months: a prospective observational study from Eastern India. Indian J Dermatol 2018; 63(1): 47-52.

45. Maymone MBC, Vankatesh S, Laughter M, Abdat R, Hugh J, Dasco MM, et al. Leprosy: treatment and management of complications. J Am Acad Dermatol 2020; 83(1):17-30.

46. Bhide AA, Khemani UN, Kamath RR, Vaidyanathan V, Ponathil AP, Kura MM. An alternative hepatosafe treatment in leprosy. Indian J Drugs Dermatol 2016; 2: 33-6.

47. Muhaira WT, Darmi M, Lubis RD. Hemolytic anemia incident in leprosy patients receiving multi-drug therapy at Haji Adam Malik Central Hospital, Medan-Indonesia. Bali Med J 2018; Vol 7( 2): 442-6.

48. Wang N, Parimi L, Liu H, Zhang F. A review on dapsone hypersensitivity syndrome among chinese patients with an emphasis on preventing adverse drug reactions with genetic testing. Am J Trop Med Hyg 2017; 96(5):1014-8.

49. Beltra n-Alzate C, Lo' pez D'iaz F, RomeroMontoya M, Sakamuri R, Li W, Kimura M, et al. Leprosy drug resistance surveillance in Colombia: the experience of a sentinel country. PLoS Negl Trop Dis 2016; 10(10): 1-12.

50. Maia MV, Cunha CS. Adverse effects of alternative therapy (minocycline, ofloxacin, and clofazimine) in multibacillary leprosy patients in a recognized health care unit in Manaus, Amazonas, Brazil. An Bras Dermatol 2013; 88(2): 205-10. 